\title{
Influence of bulla volume on postbullectomy outcome
}

\author{
S Baldi $M D^{1}$, A Palla $M D^{2}, A$ Mussi $M D^{2}, F$ Falaschi $\mathrm{MD}^{3}$, L Carrozzi MD ${ }^{2}$, \\ C Giuntini $\mathrm{MD}^{2}, \mathrm{CA}$ Angeletti $\mathrm{MD}^{2}$ \\ ${ }^{1}$ Istituto di Fisiologia Clinica CNR, ${ }^{2}$ Dipartimento Cardio Toracico, ${ }^{3}$ Dipartimento di Immagine, \\ Università di Pisa, Pisa, Italy
}

\begin{abstract}
S Baldi, A Palla, A Mussi, et al. Influence of bulla volume on postbullectomy outcome. Can Respir J 2001;8(4): 233-238.
\end{abstract}

OBJECTIVE: To quantify the contribution of the resected volume and the presence of associated, functionally significant emphysema to the postoperative improvement of pulmonary function after resection of giant lung bullae.

DESIGN: Patients undergoing elective surgery for giant bullae who had had complete pulmonary function and radiographic studies performed were reviewed retrospectively.

SETTING: All 25 patients underwent surgery at the thoracic surgery unit of the University of Pisa, Pisa, Italy.

METHODS: Pulmonary function was assessed before and 12 months after surgery. On the chest radiograph, the location of bullae, and the signs of compression and emphysema were evaluated. The radiographic total lung capacity $\left(\mathrm{TLC}_{\mathrm{X} \text {-ray }}\right)$ and the volume of bullae were measured according to the ellipse method. Postoperatively, functional and radiographic changes were analyzed. The percentage change in forced expiratory volume in $1 \mathrm{~s}\left(\Delta \mathrm{FEV}_{1} \%\right)$ after surgery was the main outcome measure. The influence of factors related to emphysema and bulla volume on the functional improvement postbullectomy was assessed by stepwise multiple regression.

RESULTS: Before surgery, the $\mathrm{TLC}_{\mathrm{X} \text {-ray }}$ overestimated the TLC measured by nitrogen washout, with a mean difference between the two measurements of $1.095 \mathrm{~L}$. A close relationship was found between the $\mathrm{TLC}_{\mathrm{X} \text {-ray }}$ and the plethysmographic TLC ( $\mathrm{n}=6 ; \mathrm{r}=0.95)$. After surgery, dyspnea lessened $(\mathrm{P}<0.05)$ and $\mathrm{FEV}_{1}$ increased $(\mathrm{P}<0.01)$. Statistically, the radiographic bulla volume was the single most important factor determining the $\Delta \mathrm{FEV}_{1} \%(\mathrm{r}=0.80, \mathrm{P}<0.0001)$.
CONCLUSIONS: These findings suggest that the preoperative size of bullae is the most important contributor to the improvement in ventilatory capacity after bullectomy, and that it is possible to predict the expected increase of postoperative $\mathrm{FEV}_{1}$ from preoperative bulla volume.

Key Words: Bullous emphysema; Chronic obstructive pulmonary disease; Outcome; Radiographic bulla volume; Surgery

\section{Incidence du volume des bulles sur les résul- tats post-bullectomie}

OBJECTIF : Quantifier l'incidence du volume réséqué et la présence d'emphysème associé, fonctionnellement significatif sur l'amélioration des résultats de l'exploration fonctionnelle respiratoire après la résection de bulles pulmonaires géantes.

PLAN D'ÉTUDE : On a procédé à un examen rétrospectif des patients qui avaient été opérés pour une résection non urgente de bulles géantes et qui avaient subi au préalable une exploration fonctionnelle respiratoire complète et des radiographies.

MILIEU : Tous les patients (25) ont été opérés à l'unité de soins thoraciques de l'université de Pise, en Italie.

MÉTHODE : Il y a eu exploration fonctionnelle respiratoire avant et 12 mois après l'intervention chirurgicale. On a évalué, sur les radiographies pulmonaires, la position des bulles, les signes de compression et l'emphysème. La capacité pulmonaire totale $\left(\mathrm{CPT}_{\mathrm{RX}}\right)$ à la radiographie et le volume des bulles ont été mesurés selon la formule de l'ellipse. Les variations fonctionnelles et radiographiques ont fait l'objet d'analyses après l'opération. La principale mesure de résultats consistait dans les écarts de pourcentage du volume expiratoire maximum en une seconde (VEMS) après l'intervention. A également été évaluée l'incidence des facteurs liés à l'emphysème et au volume des bulles sur l'amélioration fonctionnelle post-bullectomie à l'aide de la régression multiple graduelle. RÉSULTATS : Avant l'intervention, il y a eu surévaluation, par la $\mathrm{CPT}_{\mathrm{RX}}$, de la CPT mesurée par l'élimination de l'azote; l'écart moyen était de 1,095 1 entre les deux mesures. Une relation étroite a été établie entre la

voir page suivante 
$\mathrm{CPT}_{\mathrm{RX}}$ et la CPT par pléthysmographie $(n=6 ; r=0,95)$. Après l'intervention, on a observé une diminution de la dyspnée $(\mathrm{P}<0,05)$ et une augmentation du VEMS $(\mathrm{P}<0,01)$. Sur le plan statistique, seul le volume des bulles à la radiographie s'est avéré un facteur important d'écart du VEMS $(r=0,80 ; \mathrm{P}<0,0001)$.
CONCLUSIONS : Les résultats donnent à penser que la taille des bulles avant l'opération est le facteur le plus important de l'amélioration de la capacité ventilatoire après la bullectomie et qu'il est possible de prévoir l'augmentation du VEMS après l'opération à partir du volume des bulles avant l'opération.
$\mathrm{T}$ he surgical removal of giant bullae, ie, those occupying more than one-third of the hemithorax on chest radiograph, improves dyspnea and airflow limitation $(1,2)$. There is little improvement in lung function for bullae that occupy less than one-third of the hemithorax and when lung function is minimally impaired $(2,3)$. Also, the outcome is poor in the presence of very low forced expiratory volume in $1 \mathrm{~s}$ $\left(\mathrm{FEV}_{1}\right)$ with hypercapnia and cor pulmonale, unless compressed lung adjacent to a bulla is released by operation $(4,5)$. Thus, the assessment of function in the nonbullous parenchyma, which is expected to re-expand after surgery, is also helpful in patient selection (6).

Previous studies support the use of pulmonary function tests in patients with giant bullae to detect those with functionally significant emphysema and to predict their postoperative improvement (7-9). A reappraisal of the role of radiological techniques in the clinical assessment of emphysema has shown that the chest radiograph helps to identify patients with functionally significant emphysema (10). Furthermore, the radiographic method originally described by Barnhard et al (11) for the determination of total lung capacity (TLC) also enables the volumetric analysis of discrete thoracic segments, and may be applied to the measurement of bulla volume.

In the present study, we examined the reliability of the chest radiograph in quantifying the contribution of the resected volume of giant bullae to the postoperative recovery of pulmonary function in patients with and without functionally significant emphysema. The study was designed to investigate the relationship between volume of bulla, as assessed by Barnhard's method, and postoperative change in $\mathrm{FEV}_{1}$. Clinical, radiographic and functional postsurgical results were also analyzed.

\section{PATIENTS AND METHODS}

Between 1977 and 1994, 153 patients with radiographic evidence of unilateral or bilateral giant bullae underwent elective surgery for giant bullous emphysema at the Thoracic Surgery Unit of the University of Pisa, Pisa, Italy. Among them, 25 patients who had had complete physiological and radiographic studies were reviewed retrospectively. All of the pulmonary resections were performed through a unilateral thoracotomy under general anesthesia. When bilateral bullae were present, the hemithorax showing the largest bulla and/or radiographic signs of compression was operated on.

Preoperatively and postoperatively, dyspnea was graded according to the British Medical Council Questionnaire (12), and pulmonary function tests were measured according to standard techniques (13). Functional residual capacity was measured by nitrogen washout. In six of 25 patients, thoracic gas volume at end-tidal expiration was measured in a con- stant volume body plethysmograph by panting at slow frequency (approximately $0.5 \mathrm{~Hz}$ ) against a closed shutter. Carbon monoxide diffusing capacity ( $\mathrm{D} \mathrm{CO}$ ) was determined by the single breath technique (14). All of the measured data were expressed as a percentage of predicted values according to the respective reference equations. Reference values for slow vital capacity and expiratory flow rates were derived from Paoletti et al (15). For static lung volumes other than vital capacity, the predicted values were derived from Goldman and Becklake (16). For single breath $\mathrm{D}_{\mathrm{CO}}$, the reference data of Cotes (17) were used. Also, the arterial tensions of oxygen and carbon dioxide were obtained. A chest radiograph and a computed tomography (CT) scan, whenever available, completed the investigation.

A standard $2 \mathrm{~m}$ focus-to-film distance was used. To reduce motion artifact, the exposure time was kept as short as possible and was usually within $0.05 \mathrm{~s}$. The kilovolt age was adjusted to each patient's body build.

The chest radiographs were independently read by two readers - one who was a chest radiologist and the other who was a chest physician. The reading file included the evaluation of unilateral or bilateral location of bullae, signs of compression (ie, mediastinal shift and/or herniation), and signs of overinflation and pulmonary vascular abnormalities known to be associated with emphysema (10). On the preoperative chest radiograph, the radiographic TLC $\left(\mathrm{TLC}_{\mathrm{x} \text {-ray }}\right)$ was measured and the bulla volume was calculated with the assumption that both were elliptical cylindroids according to the method of Barnhard et al (11). In the posteroanterior and lateral views, the outer borders of bullae were outlined with a wax pencil; on the posteroanterior view, the longest diameter of this area (height), and the perpendiculars from this line to the furthest point to the left and right borders of the bulla, were measured. The sum of these two lines was used as the anteroposterior diameter; on the lateral view, the longest possible line roughly perpendicular to the long diameter (transverse diameter) was traced. The measurements were corrected for the divergence of the $\mathrm{x}$-ray beam by subtracting $10 \%$. The bulla volume $(\mathrm{V})$ was calculated by the following equation:

$\mathrm{V}=1 / 4 \pi \times$ transverse diameter $\times$ anteroposterior diameter $\times$ height

Also, in the 15 patients who underwent the examination, the hard copies of CT scans were analyzed according to the ellipse method (11). The longest transverse and anteroposterior diameters were identified and measured. The height was calculated by summing the thickness of the slices in which the bulla was visible. The radiographic and CT scan volumes of bullae were then compared in this subset of patients.

Postoperatively, functional and radiographic changes 
TABLE 1

Radiographic qualitative evaluation, operative findings and surgical procedures in 25 patients who underwent elective surgery for giant bullae

\begin{tabular}{|c|c|c|c|c|c|c|}
\hline \multirow[b]{2}{*}{ Patient } & \multirow[b]{2}{*}{ Age (years) } & \multicolumn{2}{|c|}{ Chest radiography qualitative evaluation } & \multicolumn{2}{|c|}{ Operative findings } & \multirow[b]{2}{*}{ Operation } \\
\hline & & $\begin{array}{c}\text { Signs of } \\
\text { compression* }\end{array}$ & $\begin{array}{l}\text { Overinflation plus } \\
\text { vascular destruction }\end{array}$ & $\begin{array}{l}\text { Site and aspect } \\
\text { of bullae }\end{array}$ & Size of bullae ${ }^{\dagger}$ & \\
\hline 1 & 17 & $\mathrm{~S} ;-$ & - & RUL, multiple bullae & ++ & Lobectomy \\
\hline 2 & 27 & $-;-$ & - & LUL, multiple bullae & +++ & Bullectomy \\
\hline 3 & 61 & S;- & E & LLL, giant bulla & ++ & Bullectomy \\
\hline 4 & 77 & $\mathrm{~S} ;-$ & E & RUL, multiple bullae & ++ & Bullectomy \\
\hline 5 & 48 & S;- & E & LUL, multiple bullae & +++ & Bullectomy \\
\hline 6 & 69 & $-;-$ & E & LLL, multiple bullae & ++ & Bullectomy \\
\hline 7 & 41 & $\mathrm{~S} ;-$ & E & RUL, giant bulla & + & Bullectomy \\
\hline 8 & 54 & $\mathrm{~S} ; \mathrm{H}$ & E & LUL, multiple bullae & +++ & Plication and packing \\
\hline 9 & 46 & $\mathrm{~S} ; \mathrm{H}$ & E & RUL, multiple bullae & +++ & Bullectomy \\
\hline 10 & 42 & $\mathrm{~S} ; \mathrm{H}$ & E & RUL, giant bulla & +++ & Bullectomy \\
\hline 11 & 45 & S;-- & - & RUL, multiple bullae & + & Bullectomy \\
\hline 12 & 63 & $-;-$ & - & LLL, giant bulla & + & Bullectomy \\
\hline 13 & 21 & S;- & - & RUL, giant bulla & ++ & Bullectomy \\
\hline 14 & 42 & $-;-$ & - & RUL, multiple bullae & ++ & Bullectomy \\
\hline 15 & 37 & $\mathrm{~S} ; \mathrm{H}$ & - & RUL, giant bulla & +++ & Bullectomy \\
\hline 16 & 40 & $\mathrm{~S} ; \mathrm{H}$ & - & RUL, multiple bullae & + & Bullectomy \\
\hline 17 & 20 & $-;-$ & - & RUL, giant bulla & + & Plication and packing \\
\hline 18 & 47 & S;- & - & RUL, multiple bullae & ++ & Plication and packing \\
\hline 19 & 66 & $\mathrm{~S} ;-$ & E & LUL, multiple bullae & + & Bullectomy \\
\hline 20 & 43 & $-;-$ & - & LUL, multiple bullae & + & Bullectomy \\
\hline 21 & 59 & $\mathrm{~S} ;-$ & E & RUL, giant bulla & ++ & Bullectomy \\
\hline 22 & 61 & S;- & E & RUL, giant bulla & + & Bullectomy \\
\hline 23 & 32 & S;- & - & RUL, giant bulla & + & Bullectomy \\
\hline 24 & 60 & $-;-$ & E & LUL, giant bulla & ++ & Bullectomy \\
\hline 25 & 47 & $-;-$ & - & RUL, multiple bullae & + & Plication \\
\hline
\end{tabular}

${ }^{*}$ Signs of compression are listed in the following order: 1) mediastinal shift (S); 2) mediastinal herniation (H); ${ }^{\dagger}$ The sizes of bullae were evaluated by the surgeon at the opening of the chest: + Less than one-half of the hemithorax; ++ Greater than one-half of the hemithorax; +++ Hemithorax. E Presence of emphysema in peribullous parenchyma; LLL Left lower lobe; LUL Left upper lobe; RUL Right upper lobe

were analyzed. The percentage change in $\mathrm{FEV}_{1}(\triangle \mathrm{FEV} \%)$ after bullectomy was expressed by the following equation:

$$
\begin{gathered}
\Delta \mathrm{FEV}_{1} \%= \\
\text { (postoperative value }- \text { preoperative value }) \\
\times 100 / \text { preoperative value }
\end{gathered}
$$

The relationship of the postoperative $\Delta \mathrm{FEV}_{1} \%$ with radiographic and functional measurements was investigated to predict the contribution of the resected volume of bullae, the compression signs and the several physiological indexes to the increase of postoperative ventilatory function.

Statistical analysis: The reproducibility of radiographic chest signs was evaluated by assessing interobserver variation using Spearman rank correlation coefficients. For variables scored in a dichotomous fashion (present/absent), the interobserver agreement was tested by means of the kappa statistic (18). The parametric paired $t$ test and the nonparametric Wilcoxon's signed rank test were used to analyze differences before and after surgery. Stepwise multiple regressions of $\triangle \mathrm{FEV}_{1} \%$ with radiographic measurements of bulla volume, $\mathrm{TLC}_{\mathrm{X} \text {-ray }}$, residual volume, $\mathrm{FEV}_{1}$ and radiological signs of compression were derived to identify the predictors of improvement in ventilatory function. $\mathrm{P}<0.05$ was accepted as indicating statistical significance. Data throughout the text are given as mean \pm SD.

\section{RESULTS}

Clinical and physiological assessments were obtained before and at a mean of 12.7 months after surgery. There were 23 men and two women with an average age of 47 years (range 17 to 77 years).

Preoperative radiographic findings, operative findings and surgical procedures are listed in Table 1 . The surgical procedures, performed through unilateral thoracotomies, comprised bullectomy in 20 patients, plication and packing in four patients, and lobectomy in one patient. Three of the 25 patients died due to respiratory failure at four months, one year and two years, respectively. Postoperatively, incomplete reexpansion with high hemidiaphragm occurred in one of 25 patients, and mediastinal herniation of the opposite lung occurred in two of 25 patients.

Before and after surgery, the chest radiograph readings were highly reproducible. When bulla dimensions were con- 


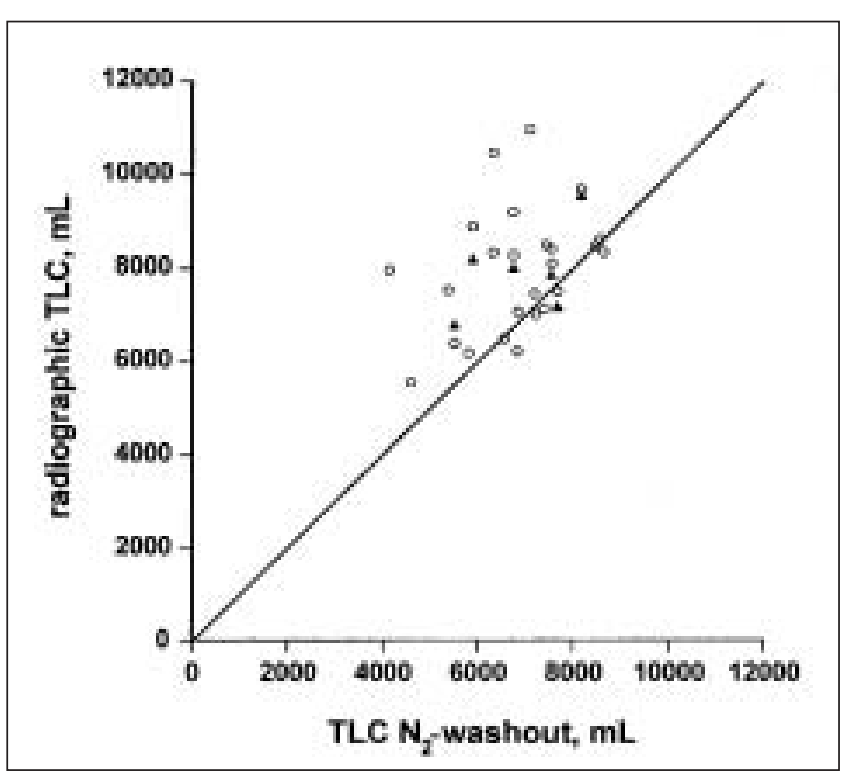

Figure 1) Comparison of the radiographic total lung capacity (TLC) (measured according to the method of Barnhard et al [11]) with the nitrogen washout TLC (TLC N2-washout) technique (open circles). Radiographic TLC overestimated TLC $N_{2}$-washout ( $r=0.36$, not significant). The dotted line is the line of identity. The solid triangles represent measurements $(n=6)$ obtained by means of body plethysmography. The relationship between radiographic TLC and plethysmographic TLC is strong $(r=0.95, P<0.001)$

sidered, Spearman rank correlation coefficients were statistically significant $(\mathrm{P}<0.001)$. Values of kappa coefficients for variables scored in a dichotomous fashion (location of bullae, signs of compression and signs of emphysema) were also statistically significant $(\mathrm{P}<0.01)$. The average of the readings made by the two reviewers was used for the analyses.

On chest radiography, bilateral bullae were present in eight of 25 patients (32\%). In these patients, the bullae contralateral to the operated side occupied less than one-half of the hemithorax. Radiographic signs of emphysema were present in 12 of 25 patients (48\%), and signs of compression of peribullous parenchyma - ie, mediastinal shift and mediastinal herniation - were present in 17 patients (68\%) and five patients (20\%), respectively (Table 1 ).

The $\mathrm{TLC}_{\mathrm{x} \text {-ray }}$ was $7963 \pm 1322 \mathrm{~mL}$. The radiographic volume of bullae that were resected was $1448 \pm 759 \mathrm{~mL}$ (range 566 to $4187 \mathrm{~mL}$ ). Figure 1 shows TLC $_{\mathrm{X} \text {-ray }}$ plotted against nitrogen-washout TLC (TLC $\mathrm{N}_{2}$-washout) and the line of identity ( $\mathrm{r}=0.36$, not significant). The total lung volume measured by the ellipse method tended to overestimate the measure-

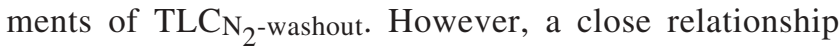
was found between $\mathrm{TLC}_{\mathrm{X} \text {-ray }}$ and plethysmographic TLC $(r=0.95, P<0.001)$ in the six patients who underwent this measurement (shown as solid triangles in Figure 1).

Figure 2 shows the close relationship between bulla volume measured by $\mathrm{CT}$ scan and the corresponding value measured on the chest radiograph $(\mathrm{r}=0.79, \mathrm{P}<0.01)$ in a subset of 15 patients.

In Table 2, changes in dyspnea and pulmonary function

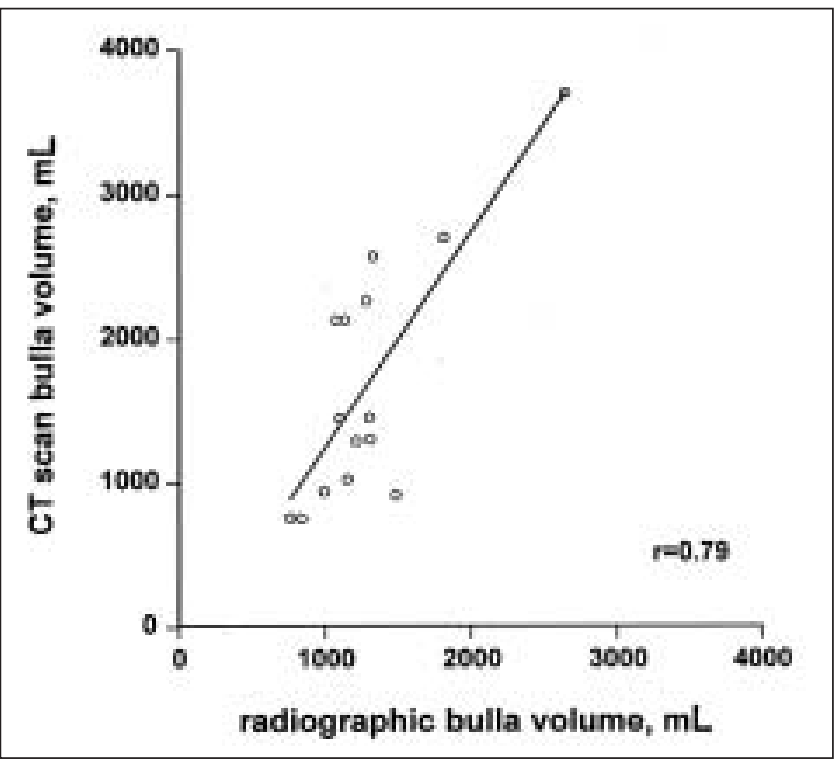

Figure 2) Comparison of bulla volumes measured on chest radiograph with those measured by thoracic computed tomography $(C T)$ scan $(r=0.80, P<0.001)$ in a subset of 15 patients

TABLE 2

Changes (mean $\pm \mathrm{SD})$ in dyspnea, tobacco consumption and lung function in 25 patients who underwent elective surgery for giant bullae

\begin{tabular}{|c|c|c|c|}
\hline & $\begin{array}{l}\text { Before } \\
\text { operation }\end{array}$ & $\begin{array}{c}\text { After } \\
\text { operation }\end{array}$ & $\mathbf{P}$ \\
\hline Dyspnea (grade) & $1.9(1.0)$ & $1.0(1.0)$ & $*$ \\
\hline Pack-years & $25(19)$ & $26(20)$ & NS \\
\hline Vital capacity (\% pred) & $95(23)$ & $101(24)$ & NS \\
\hline Residual volume (\% pred) & $145(67)$ & $128(60)$ & NS \\
\hline FRC (\% pred) & $122(35)$ & $118(39)$ & NS \\
\hline Total lung capacity (\% pred) & $114(16)$ & $128(17)$ & NS \\
\hline Forced vital capacity (\% pred) & $81(21)$ & $88(20)$ & $\dagger$ \\
\hline $\mathrm{FEV}_{1}(\%$ pred $)$ & $57(29)$ & $67(29)$ & $\ddagger$ \\
\hline $\mathrm{FEV}_{1} /$ vital capacity (\%) & $49(17)$ & $56(17)$ & $\ddagger$ \\
\hline $\mathrm{D}_{\mathrm{co}}(\%$ pred $)$ & $67(26)$ & $71(28)$ & NS \\
\hline $\mathrm{PaO}_{2}(\mathrm{mmHg})$ & $81(12)$ & $84(14)$ & NS \\
\hline $\mathrm{PaCO}_{2}(\mathrm{mmHg})$ & $42(4)$ & $44(5)$ & NS \\
\hline
\end{tabular}

${ }^{\star} P<0.05$ by Wilcoxon's signed rank test; ${ }^{\dagger} P<0.05 ;{ }^{\ddagger} P<0.01$. D Co Single breath carbon monoxide diffusion capacity; FEV $V_{1}$ Forced expiratory volume in $1 \mathrm{~s}$; FRC Functional residual capacity; NS Not significant; $\%$ pred Percentage of the predicted normal value; $\mathrm{PaCO}_{2}$ Arterial carbon dioxide tension; $\mathrm{PaO}_{2}$ Arterial oxygen tension

tests after surgery are reported. Dyspnea lessened significantly $(\mathrm{P}<0.05)$ and the percentage of the predicted normal value of $\mathrm{FEV}_{1}$ increased significantly $(\mathrm{P}<0.01)$.

The $\triangle \mathrm{FEV}_{1} \%$ was positive in all patients, with the exception of patient number 19, in whom there was incomplete re-expansion with a high hemidiaphragm postoperatively. In this patient, the $\triangle \mathrm{FEV}_{1} \%$ fell by $39 \%$; this patient was not included in the subsequent analyses. The $\Delta \mathrm{FEV}_{1} \%$ in the other 24 patients was $34 \pm 31$. 
Stepwise multiple linear regression analysis showed that the $\triangle \mathrm{FEV}_{1} \%$ was related mainly to the volume of bullae resected (Figure 3); the inclusion of additional variables such as preoperative arterial tension of carbon dioxide, residual volume, $\mathrm{FEV}_{1}, \mathrm{D}_{\mathrm{CO}}, \mathrm{TLC}_{\mathrm{x} \text {-ray }}$ and signs of compression did not significantly improve the correlation, which took the following form:

$$
\Delta \mathrm{FEV}_{1} \%=-5.82+0.028 \times \text { bulla volume }(\mathrm{mL})
$$

On chest radiography, no new bullae were seen in the operated lung during the year of follow-up. The compression signs caused from bullae disappeared in all patients after bullectomy, indicating decompression of the peribullous parenchyma.

\section{DISCUSSION}

The results of the present study confirm that bullectomy improves dyspnea and airflow obstruction in patients with giant bullae, with or without the association of functionally significant emphysema $(1,9,19-25)$.

The finding that the volume of the resected bulla is statistically the single most important contributor to the $\triangle \mathrm{FEV}_{1} \%$ leads to the conclusion that a bulla contributes to airflow obstruction that is reversible after bullectomy, independent of the presence of coexisting emphysema. Also, the relationship between $\Delta \mathrm{FEV}_{1} \%$ and bulla volume may enable postoperative improvement in ventilatory function to be predicted with a simple and clinically useful formula.

The volumetric analysis of bulla volume was performed according to the method described by Barnhard et al (11) for determination of TLC. In the present study, $\mathrm{TLC}_{\mathrm{X} \text {-ray }}$

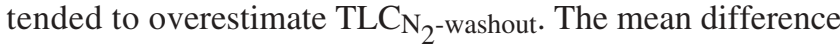
of $1.095 \mathrm{~L}$ is similar to a previously reported value (11). This difference is not surprising in patients who have between $566 \mathrm{~mL}$ and $4187 \mathrm{~mL}$ of gas trapping (26). Also, the $\mathrm{TLC}_{\mathrm{X} \text {-ray }}$ was closely related to plethysmographic TLC $(r=0.95)$ in six patients who underwent this measurement. Thus, our findings tend to validate the radiographic method for measuring both the TLC and the volume of giant bullae.

Thoracic CT has been recognized as the method of choice to measure the total lung volume (27) and the volume of bullae (28) accurately, and to quantify emphysema in the nonbullous parenchyma $(29,30)$. Thus, we believe it should be added to the preoperative functional evaluation of bullous emphysema. In the present study, we did not perform a densitometric analysis of CT scans because only the hard copies of CT scans from 15 patients were available to us. In the remaining 10 patients, CT scans were performed at different hospitals.

Although the measurements from chest radiographs would have underestimated the presence of some small bullae $(31,32)$ and subclinical emphysema in nonbullous parenchyma (30), our findings confirmed the value of the chest radiograph in the quantitative evaluation of well localized areas of compressed lung in giant bullous emphysema. Moreover, in the 15 patients who had a CT scan, we found a close relationship between the volume of bullae measured by the ellipse

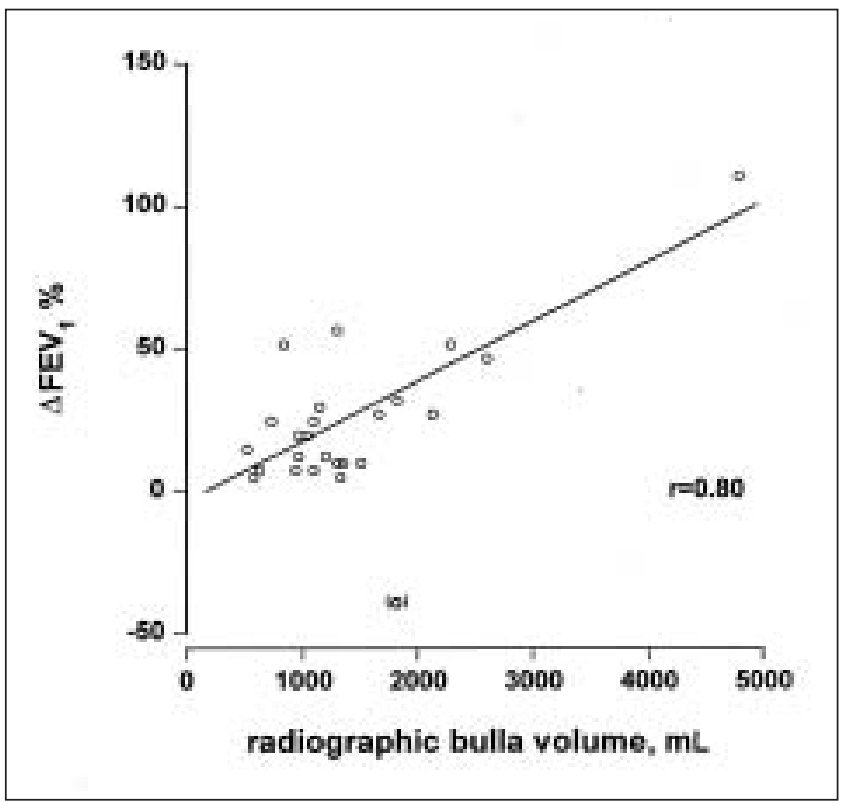

Figure 3) Linear regression analysis of percentage change in forced expiratory volume in $1 s\left(\triangle F E V_{1} \%\right)$ versus bulla volume as assessed by geometric measurements from chest radiograph (ellipse method) in 24 patients. The regression equation was $y=-5.82+0.028 x$, and there was a statistically significant correlation coefficient $(r=0.80$, $P<0.0001)$. The open circle in brackets refers to patient number 19, who was not included in the correlation because of incomplete reexpansion with a high hemidiaphragm postoperatively

method on both CT scan hard copies and chest radiographs $(\mathrm{r}=0.79, \mathrm{P}<0.01)$ (Figure 2).

\section{CONCLUSIONS}

We found a postoperative increase in $\mathrm{FEV}_{1}$ of approximately $20 \%$ over the preoperative value in patients undergoing bullectomy. The extent of improvement may be predicted by means of quantitative assessment of the chest radiograph, which may be of practical value when elective surgery is under consideration for patients with giant bullous emphysema.

\section{REFERENCES}

1. FitzGerald MX, Keelan PJ, Cugell DW, Gaensler EA. Long-term results of surgery for bullous emphysema. J Thorac Cardiovasc Surg 1974;68:566-87.

2. Snider GL. Reduction pneumoplasty for giant bullous emphysema. Implications for surgical treatment of nonbullous emphysema. Chest 1996;109:540-8.

3. Nickoladze GD. Functional results of surgery for bullous emphysema. Chest 1992;101:119-22.

4. Gaensler EA, Cugell DW, Knudson RJ, FitzGerald MX. Surgical management of emphysema. Clin Chest Med 1983;4:443-63.

5. Benfield JR, Cree EM, Pellett JR, Barbee R, Mendenhall JT, Hickey RC. Current approach to the surgical management of emphysema. Arch Surg 1966;93:59-70.

6. Klingman RR, Angelillo VA, DeMeester TR. Cystic and bullous lung disease. Ann Thorac Surg 1991;52:576-80.

7. Pride NB, Barter CE, Hugh-Jones P. The ventilation of bullae and the effect of their removal on thoracic gas volumes and tests of overall pulmonary function. Am Rev Respir Dis 1973;107:83-98.

8. Nakahara K, Nakaoka K, Onho K, et al. Functional indications for bullectomy of giant bulla. Ann Thorac Surg 1983;35:480-7. 
9. Ohta M, Nakahara K, Yasumitsu T, Ohsugi T, Maeda M, Kawashima Y. Prediction of postoperative performance status in patients with giant bulla. Chest 1992;101:668-73.

10. Miniati M, Filippi E, Falaschi F, et al. Radiologic evaluation of emphysema in patients with chronic obstructive pulmonary disease. Chest radiography versus high resolution computed tomography. Am J Respir Crit Care Med 1995;151:1359-67.

11. Barnhard HJ, Pierce JA, Joyce JW, Bates JH. Roentgenographic determination of total lung capacity. A new method evaluated in health, emphysema and congestive heart failure. Am J Med 1960;28:51-60.

12. American Thoracic Society. Lung function testing: Selection of reference values and interpretative strategies. Am Rev Respir Dis 1991;144:1202-18

13. Medical Research Council Committee on the Aetiology of Chronic Bronchitis. Definition and classification of chronic bronchitis for clinical and epidemiological purposes. Lancet 1965;i:775-9.

14. American Thoracic Society. Single-breath carbon monoxide diffusing capacity (transfer factor): Recommendations for a standard technique - 1995 update. Am J Respir Crit Care Med 1995;152:2185-98.

15. Paoletti P, Pistelli G, Fazzi P, et al. Reference values for vital capacity and flow-volume curves from a general population study. Bull Eur Physiopathol Respir 1986;22:451-9.

16. Goldman HI, Becklake MR. Respiratory function tests. Normal value at median altitudes and the prediction of normal results. Am Rev Tuberc 1959;7:457-67.

17. Cotes JE. Lung Function: Principles and Application in Medicine, 4th edn. Oxford: Blackwell Scientific Publications, 1979.

18. Fleiss JL, Nee JCM, Landish JR. Large sample variance of kappa in the case of different sets of raters. Psychol Bull 1979;86:974-7.

19. Pride NB, Hugh-Jones P, O'Brien EN, Smith LA. Changes in lung function following the surgical treatment of bullous emphysema. Q J Med 1970;39:49-69.
20. Potgieter PD, Benatar SR, Hewitson RP, Ferguson AD. Surgical treatment of bullous lung disease. Thorax 1981;36:885-90.

21. Connolly JE, Wilson A. The current status of surgery for bullous emphysema. J Thorac Cardiovasc Surg 1989;97:351-61.

22. Boushy SF, Kohen R, Billig DM, Heiman MJ. Bullous emphysema: clinical, roentgenologic and physiologic study of 49 patients. Dis Chest 1968;54:327-34.

23. Foreman S, Weill H, Duke R, George R, Ziskind M. Bullous disease of the lung: physiologic improvement after surgery. Ann Intern Med 1968;69:757-67.

24. Viola AR, Zuffardi EA. Physiologic and clinical aspects of pulmonary bullous disease. Am Rev Respir Dis 1966;94:574-83.

25. Morgan MDL, Edwards CW, Morris J, Matthews HR. Origin and behaviour of emphysematous bullae. Thorax 1989;44:533-8.

26. Bedell GN, Marshall R, DuBois AB, Comroe JH Jr. Plethysmographic determination of the volume of gas trapped in the lungs. J Clin Invest 1956;35:664-70.

27. Archer DC, Coblentz CL, deKemp RA, Nahmias C, Norman G. Automated in vivo quantification of emphysema. Radiology 1993; $188: 835-8$

28. Morgan MDL, Denison DM, Strickland B. Value of computed tomography for selecting patients with bullous lung disease for surgery. Thorax 1986;41:855-62.

29. Gould GA, Redpath AT, Ryan M, et al. Parenchymal emphysema measured by CT lung density correlates with lung function in patients with bullous disease. Eur Respir J 1993;6:698-704.

30. Thurlbeck WM, Muller NL. Emphysema: Definition, imaging, and quantification. AJR Am J Roentgenol 1994;163:1017-25.

31. Carr DH, Pride NB. Computed tomography in pre-operative assessment of bullous emphysema. Clin Radiol 1984;35:43-5.

32. Fiore D, Biondetti PR, Sartori F, Calabrò F. The role of computed tomography in the evaluation of bullous lung disease. J Comput Assist Tomogr 1982;6:105-8. 


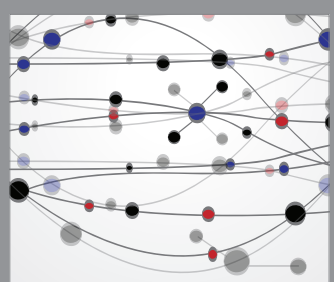

The Scientific World Journal
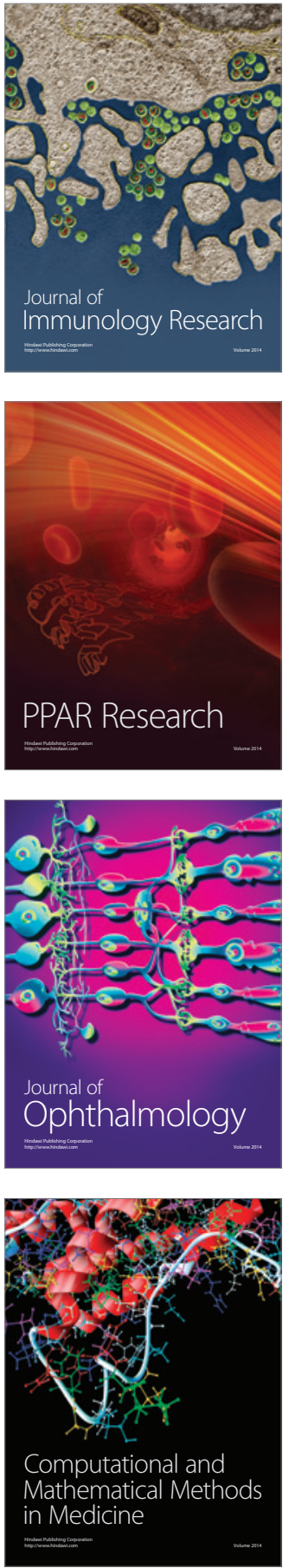

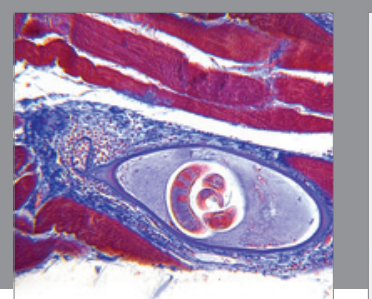

Gastroenterology Research and Practice

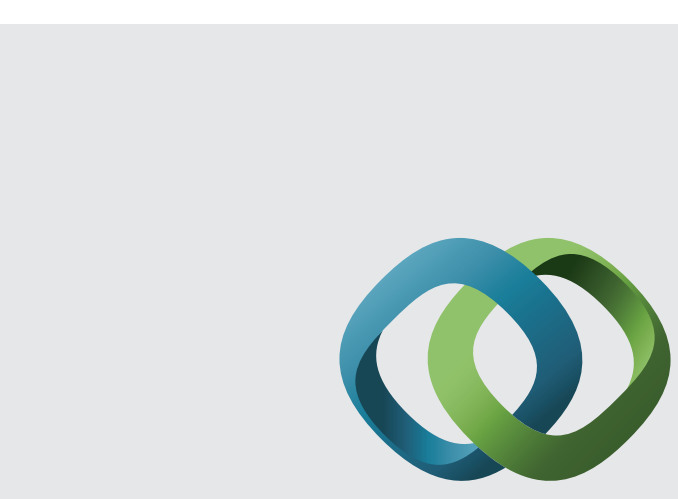

\section{Hindawi}

Submit your manuscripts at

http://www.hindawi.com
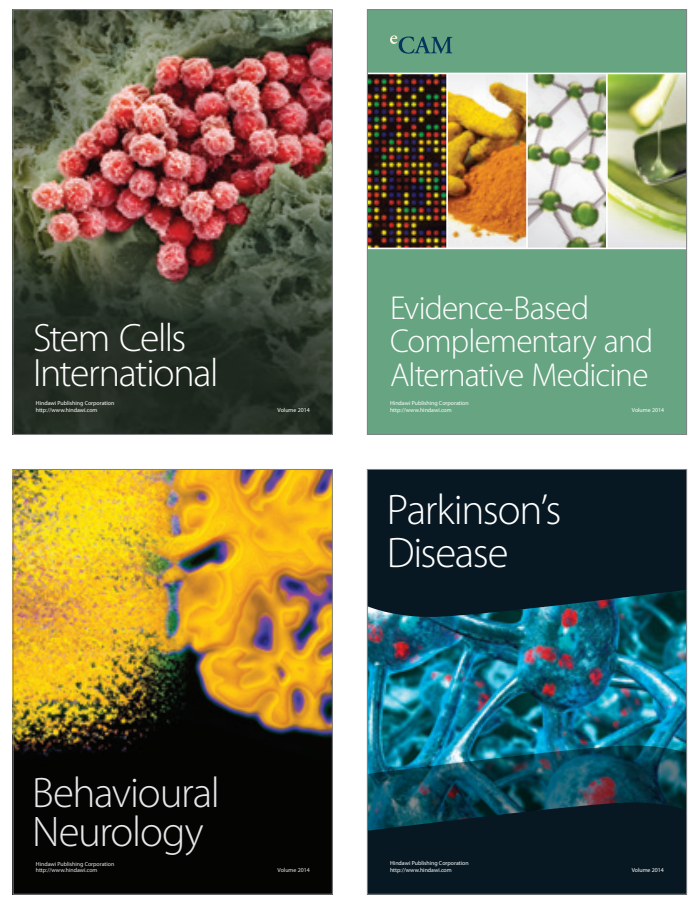
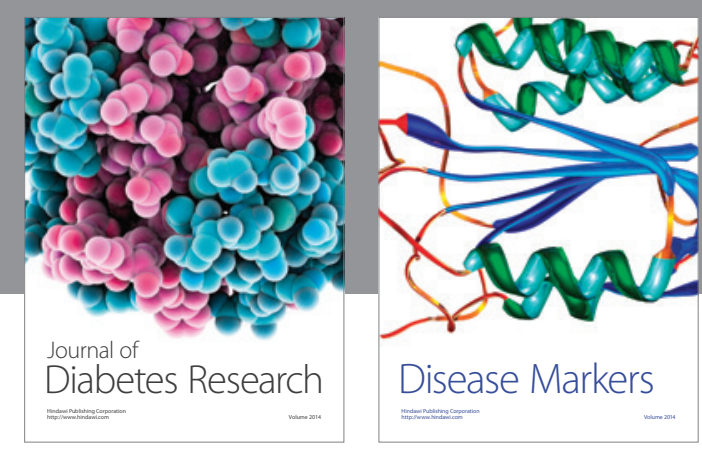

Disease Markers
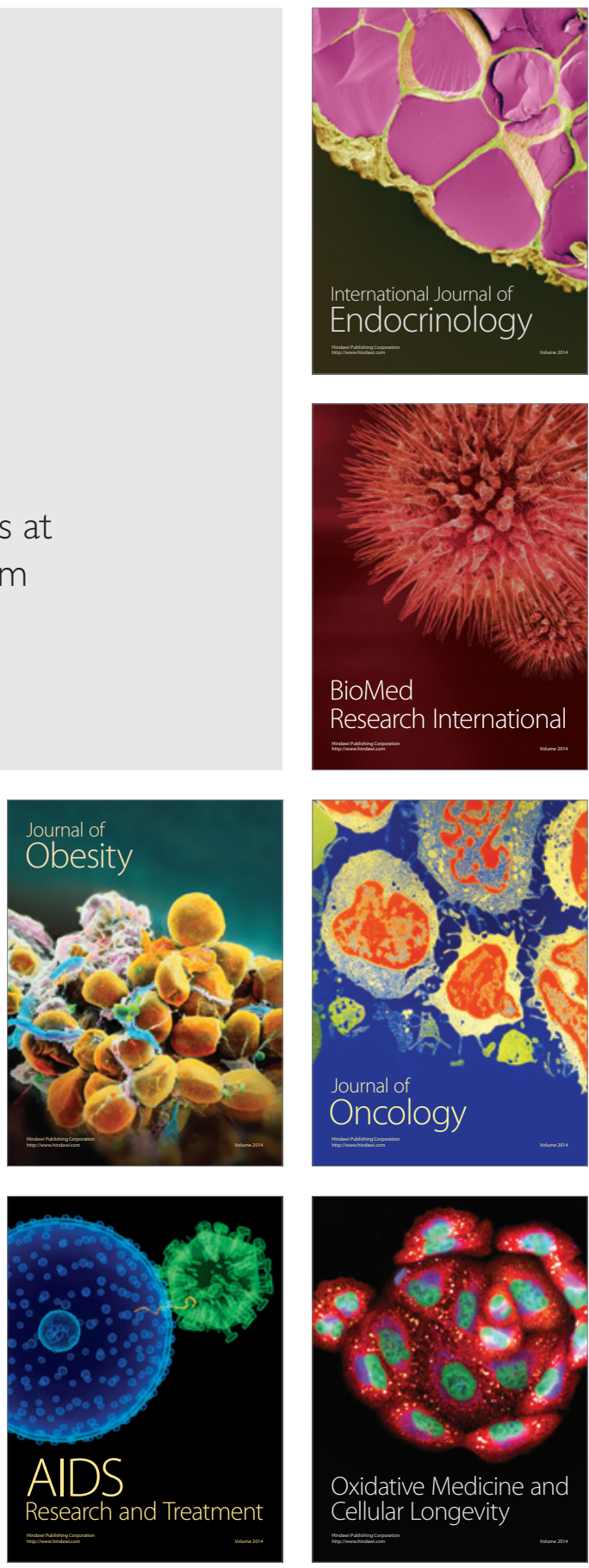